\title{
Pancreatic stellate cells are activated by proinflammatory cytokines: implications for pancreatic fibrogenesis
}

\author{
M V Apte, P S Haber, S J Darby, S C Rodgers, G W McCaughan, M A Korsten, \\ R C Pirola, J S Wilson
}

\begin{abstract}
Background-The pathogenesis of pancreatic fibrosis is unknown. In the liver, stellate cells play a major role in fibrogenesis by synthesising increased amounts of collagen and other extracellular matrix (ECM) proteins when activated by profibrogenic mediators such as cytokines and
\end{abstract} oxidant stress.

Aims-To determine whether cultured rat pancreatic stellate cells produce collagen and other ECM proteins, and exhibit signs of activation when exposed to the cytokines platelet derived growth factor (PDGF) or transforming growth factor $\beta$ (TGF- $\beta$ ).

Methods-Cultured pancreatic stellate cells were immunostained for the ECM proteins procollagen III, collagen I, laminin, and fibronectin using specific polyclonal antibodies. For cytokine studies, triplicate wells of cells were incubated with increasing concentrations of PDGF or TGF- $\beta$.

Results-Cultured pancreatic stellate cells stained strongly positive for all ECM proteins tested. Incubation of cells with 1 , 5, and $10 \mathrm{ng} / \mathrm{ml}$ PDGF led to a significant dose related increase in cell counts as well as in the incorporation of ${ }^{3} \mathbf{H}$-thymidine into DNA. Stellate cells exposed to 0.25 , 0.5 , and $1 \mathrm{ng} / \mathrm{ml}$ TGF- $\beta$ showed a dose dependent increase in $\alpha$ smooth muscle actin expression and increased collagen synthesis. In addition, TGF- $\beta$ increased the expression of PDGF receptors on stellate cells.

Conclusions-Pancreatic stellate cells produce collagen and other extracellular matrix proteins, and respond to the cytokines PDGF and TGF- $\beta$ by increased proliferation and increased collagen synthesis. These results suggest an important role for stellate cells in pancreatic fibrogenesis.

(Gut 1999;44:534-541)

Keywords: pancreatic fibrosis; stellate cell activation; cytokines

Correspondence to: Associate Professor J S Wilson, Department of Gastroenterology, Edmund Blacket Building, Prince of Wales Hospital, Randwick NSW 2031, Australia.

Accepted for publication 21 October 1998
In contrast to the pancreas, fibrogenesis in the liver has been well studied. It is now established that the hepatic stellate cell plays a central role in the production of hepatic fibrosis. ${ }^{2-4}$ In the normal liver, stellate cells are the primary storage site for vitamin $\mathrm{A}^{2}$ In liver injury, these cells are activated by various profibrogenic mediators including cytokines ${ }^{5}$ (released from Kupffer cells and activated macrophages) and oxidant stress. ${ }^{67}$ The process of stellate cell activation involves: (a) enlargement and proliferation; (b) transformation into a myofibroblast-like phenotype exhibiting positive staining for the cytoskeletal marker protein $\alpha$ smooth muscle actin ( $\alpha \mathrm{SMA}) ;(c)$ increased responsiveness to proliferative and fibrogenic cytokines (such as platelet derived growth factor (PDGF) and transforming growth factor $\beta$ (TGF- $\beta$ ) respectively) via increased expression of relevant receptors on the cell surface; and (d) increased synthesis and secretion of individual extracellular matrix (ECM) components including collagens, fibronectin, laminin, proteoglycans, and hyaluronan. It has been shown that activated hepatic stellate cells produce the major fraction of ECM proteins during hepatic fibrogenesis, with only minor contributions (if any) from hepatocytes, Kupffer cells, and bile duct epithelial cells. ${ }^{8}$

It is possible that pancreatic fibrosis is produced by a pathway similar to that in the liver, namely via activation of pancreatic stellate cells. This concept is strengthened by recent studies from our group showing that: $(a)$ the normal rat pancreas contains stellate shaped cells (identified by positive staining for the cytoskeletal markers desmin and glial fibrillary acidic protein (GFAP)), which are morphologically similar to hepatic stellate cells; and (b) in a rat model of pancreatic fibrosis and in human chronic pancreatitis, positive staining for $\alpha$ SMA is observed (suggesting the presence of activated stellate cells) in fibrotic areas. ${ }^{10}$ A method has been developed to isolate and culture pancreatic stellate cells, ${ }^{9}$ providing a novel in vitro method to study their biology. In culture, pancreatic stellate cells exhibit features identical to those

Abbreviations used in this paper: ECM, extracellular matrix; GFAP, glial fibrillary acidic protein; PGDF, platelet derived growth factor; PGDF-R, platelet derived growth factor receptor; SMA, smooth muscle actin; TGF, transforming growth factor; PLSD, Fisher's protected least significant difference test. 
described for cultured hepatic stellate cells including: abundant lipid droplets in the cytoplasm, positive autofluorescence for vitamin A, and positive staining for desmin and GFAP.

As described earlier, the morphology of pancreatic stellate cells has now been well characterised both in vivo and in vitro. In normal rat pancreas these cells exist in a quiescent, non-activated state as shown by negative staining for $\alpha$ SMA. ${ }^{9}$ By analogy with hepatic stellate cells, activation of pancreatic stellate cells might be expected to occur under conditions of pancreatic injury when there is increased production of profibrogenic factors such as cytokines $^{11}{ }^{12}$ and oxidant stress. ${ }^{13}{ }^{14}$ If pancreatic stellate cells play a role in pancreatic fibrogenesis in a manner analogous to stellate cells in the liver, it is essential to show that these cells have the ability to produce ECM proteins in response to the profibrogenic mediators. However, these functional aspects of pancreatic stellate cells have not yet been defined. Therefore, the aims of this study were to determine whether cultured pancreatic stellate cells: $(a)$ have the capacity to produce ECM proteins; and $(b)$ are activated by cytokines such as PDGF and TGF- $\beta 1$.

\section{Methods}

ISOLATION AND CULTURE OF PANCREATIC STELLATE SHAPED CELLS

Rat pancreatic stellate cells were isolated as detailed previously, ${ }^{9}$ by a modification of the method described by Schafer et al in the liver. ${ }^{15}$ Briefly, the pancreas was digested with a mixture of collagenase $\mathrm{P}(0.05 \%)$, pronase $(0.02 \%)$, and DNAse $(0.1 \%)$ in Gey's balanced salt solution. The resultant suspension of cells was centrifuged in a $13.2 \%$ Nycodenz gradient at $1400 \mathrm{~g}$ for 20 minutes. Stellate cells separated into a fuzzy band just above the interface of the Nycodenz solution and the aqueous buffer. This band was harvested, and the cells were washed and then resuspended in Iscove's modified Dulbecco's medium containing $10 \%$ fetal bovine serum, $4 \mathrm{mM}$ glutamine, and antibiotics (penicillin 100 units $/ \mathrm{ml}$; streptomycin $100 \mu \mathrm{g} / \mathrm{ml})$. The above technique yields a preparation of stellate cells devoid of contamination by endothelial cells or macrophages as evidenced by negative staining for the markers factor VIII and ED1 respectively.

Freshly isolated stellate cells were cultured in 24 well culture plates (for cytokine experiments) or Nunc chamber slides (for immunocytochemistry).

IMMUNOCYTOCHEMISTRY FOR ECM PROTEINS (PROCOLLAGEN III, COLLAGEN I, FIBRONECTIN, AND LAMININ)

Cells cultured in Nunc chamber slides were washed in Hank's balanced salt solution (HBSS), fixed in acetone at $4^{\circ} \mathrm{C}$ for 10 minutes, and air dried. After washing for five minutes with three changes of $1 \times$ Tris buffered saline (TBS) at room temperature, cells were incubated with $1 \% \mathrm{H}_{2} \mathrm{O}_{2}$-methanol for 30 minutes to block endogenous peroxidase activity. After further washes, cells were exposed to a blocking solution to prevent non-specific binding of antibody as follows: cells to be examined for procollagen III, laminin, and fibronectin were incubated with TBS containing $10 \%$ goat serum and $1 \%$ bovine serum albumin (BSA) whereas those to be examined for collagen I were incubated with TBS containing $10 \%$ swine serum and $1 \%$ BSA. Cells were then incubated with the primary antibody (polyclonal rabbit antiprocollagen III antibody diluted 1 in 20, polyclonal rabbit anticollagen I antibody diluted 1 in 50, polyclonal rabbit antilaminin antibody diluted 1 in 30 , or polyclonal rabbit antifibronectin antibody diluted 1 in 50) in the appropriate blocking solution overnight at $4^{\circ} \mathrm{C}$. After three washes in TBS for five minutes each, cells to be tested for procollagen III, laminin, and fibronectin were incubated for 60 minutes at room temperature with peroxidase conjugated goat antirabbit IgG diluted 1 in 100 in TBS containing $10 \%$ goat serum and $1 \%$ BSA. Cells tested for collagen I were incubated with alkaline phosphatase conjugated swine antirabbit IgG diluted 1 in 100 in TBS containing 10\% swine serum and $1 \%$ BSA. Colour was developed using the Sigma liquid diaminobenzidine (DAB) substrate-chromogen system (for procollagen III, laminin, and fibronectin) and the Sigma liquid fast red-naphthol substratechromogen system for collagen I. Cells were then counterstained with Mayer's haematoxylin for five minutes. Stellate cells incubated with the appropriate preimmune host serum served as negative controls.

\section{DETERMINATION OF CELL PROLIFERATION IN} RESPONSE TO PDGF

Cultured pancreatic stellate cells were passaged twice and replated at equal seeding densities into 24 well culture plates. Triplicate wells of cells were then exposed to the PDGF isoform PDGF-BB in increasing concentrations ( 1,5 , and $10 \mathrm{ng} / \mathrm{ml}$ culture medium) for 48 hours. Cells incubated in medium without PDGF-BB served as controls. The rate of cell proliferation after exposure to PDGF-BB was assessed using two parameters-cell counts per well and rate of DNA synthesis as measured by the incorporation of ${ }^{3} \mathrm{H}$-thymidine into trichloroacetic acid (TCA) precipitable material.

\section{Cell counts}

Cells were washed twice in HBSS, harvested by trypsinisation using $0.5 \%$ trypsin- $-0.2 \%$ EDTA, resuspended in $200 \mu \mathrm{l}$ culture medium, and counted using a haemocytometer.

DNA synthesis (incorporation of ${ }^{3} H$-thymidine) For the final 16 hours of the 48 hour incubation with PDGF-BB, cells were pulsed with ${ }^{3} \mathrm{H}$-thymidine at a concentration of $5 \mu \mathrm{Ci}$ per well. The reaction was stopped by aspirating the medium and cells were washed twice with HBSS. Ice cold $10 \%$ TCA was added to the wells and cells incubated for 10 minutes at $4^{\circ} \mathrm{C}$. This was followed by a further two incubations with 5\% TCA for 10 minutes each at $4^{\circ} \mathrm{C}$. A $500 \mu \mathrm{l}$ aliquot of $1 \mathrm{~N} \mathrm{NaOH}$ was added to the wells which were shaken on a rotary shaker at room temperature for 30 minutes. 
The reaction was stopped by adding $500 \mu 11 \mathrm{~N}$ HC1. The mixture was transferred to scintillation vials and radioactivity of the samples was measured using a liquid scintillation counter (Tricarb 4000 Series, Canberra Packard, Five Dock, NSW, Australia).

ASSESSMENT OF STELLATE CELL ACTIVATION IN RESPONSE TO TGF- $\beta 1$

Cells at passage 3, plated at equal seeding density in 24 well culture plates, were used for TGF- $\beta 1$ studies. Triplicate wells of cells were incubated with TGF- $\beta 1$ at concentrations of $0.25,0.5$, and $1 \mathrm{ng} / \mathrm{ml}$ culture medium for 48 hours at $37^{\circ} \mathrm{C}$ in a $5 \% \mathrm{CO}_{2}$-air humidified atmosphere. Cells incubated without TGF- $\beta 1$ were used as controls. Stellate cell activation was assessed by determination of expression of aSMA and by measurement of collagen synthesis. The effect of TGF- $\beta 1$ on the expression of PDGF receptors, specifically the $\beta$ subunit of the PDGF receptor (PDGF-R $\beta$ ), on the surface of pancreatic stellate cells was also examined.

\section{aSMA expression}

Concentrations of $\alpha \mathrm{SMA}$ in cells incubated with and without TGF- $\beta 1$ were estimated by western blotting of cell lysate proteins, using a monoclonal mouse antibody to aSMA. Briefly, cells were harvested by trypsinisation, and cell lysates were obtained by incubating the cells overnight in lysis buffer $(50 \mathrm{mM}$ Tris $\mathrm{HCl}(\mathrm{pH}$ 7.5), $150 \mathrm{mM} \mathrm{NaCl}, 1 \%$ Triton $\mathrm{X}-100,0.5 \%$ deoxycholate, $1 \%$ sodium dodecyl sulphate (SDS), $1 \mathrm{mM} \mathrm{Na}$ orthovanadate, $2 \mathrm{mM}$ EDTA, $10 \mathrm{mM} \mathrm{NaF}, 10 \mu \mathrm{g} / \mathrm{ml}$ aprotinin, 10 $\mu \mathrm{g} / \mathrm{ml}$ leupeptin, $1 \mathrm{mM}$ phenylmethylsulphonyl fluoride). ${ }^{16}$ Samples were then centrifuged at $2200 \mathrm{~g}$ for 10 minutes and the supernatant was harvested for measurement of $\alpha$ SMA concentrations.

Immunoblotting for aSMA-Protein concentrations in cell lysates were measured by the method of Lowry et $a l^{17}$ using BSA as the standard. Proteins $(15 \mu \mathrm{g})$ from each sample were separated by gel electrophoresis using a $15 \%$ SDS-polyacrylamide gel. Known molecular weight protein standards were run alongside the samples. Separated proteins were transferred onto a nitrocellulose membrane using a commercial semidry blotting apparatus (Biorad, Richmond, California, USA). The nitrocellulose membrane was then incubated at room temperature with $5 \%$ skimmed milk powder in TBS ( $\mathrm{pH}$ 7.6) for one hour to prevent non-specific binding of antibody. This was followed by an overnight incubation at $4^{\circ} \mathrm{C}$ with the primary antibody (monoclonal mouse anti- $\alpha$ SMA antibody diluted 1 in 200) in fresh blocking solution. The filter was then washed and incubated with the secondary antibody (goat antimouse IgG diluted 1 in 500; Amersham International, Buckinghamshire, UK) for 60 minutes at room temperature. aSMA bands were detected by the enhanced chemiluminescence technique using the Amersham ECL kit and quantitated by densitometry of scanned autoradiographs (Scanalytics One-D Scan, Boston, Massachusetts, USA).
Densitometry readings were expressed as integrated optical densities (arbitrary densitometer units calculated from the density as well as the size of each band) per $\mu \mathrm{g}$ protein loaded onto the membranes.

\section{Collagen synthesis}

Collagen synthesis was assessed in cells incubated with and without TGF- $\beta 1$ by measuring the incorporation of radiolabelled proline into collagenase sensitive protein, using a modification of the method of Agelli and Wahl. ${ }^{18}$ Briefly, cells were incubated for one hour in prolinefree medium and then labelled for 16 hours with $2 \mu \mathrm{Ci} / \mathrm{ml}{ }^{14} \mathrm{C}$-proline in Dulbecco's medium containing $1 \%$ fetal bovine serum, 50 $\mu \mathrm{g} / \mathrm{ml}$ ascorbic acid (freshly made), and 75 $\mu \mathrm{g} / \mathrm{ml} \beta$-aminoproprionitrile. At the end of the incubation period, culture medium in the wells was aspirated and kept aside. Cells were harvested by trypsinisation, washed, and added to the reserved medium. The samples were sonicated for 90 seconds and proteins were precipitated with $10 \%$ TCA (final concentration). TCA treated samples were centrifuged at $1000 \mathrm{~g}$ for 10 minutes and the pellet (comprising precipitated protein) was solubilised in 200 $\mu 10.2 \mathrm{~N} \mathrm{NaOH}$. After neutralisation with $0.2 \mathrm{~N}$ $\mathrm{HCl}$, samples were divided into two equal aliquots. One aliquot was incubated with collagenase solution (containing $6.25 \mathrm{mM} \mathrm{CaCl}$, $70 \mathrm{mM}$ Tris ( $\mathrm{pH}$ 7.4), $30 \mathrm{mM}$ N-ethylmaleimide (NEM) and 360 units/ml collagenase type III) whereas the other aliquot was incubated with the above solution in the absence of collagenase for 120 minutes at $37^{\circ} \mathrm{C}$. Incorporation of ${ }^{14} \mathrm{C}$-proline into collagen and non-collagen protein was determined following precipitation with TCA. Collagen incorporated radioactivity was recovered in the TCA soluble fraction whereas non-collagen radioactivity was found in the TCA precipitate. Collagen production was determined using formulae derived by Peterkofsky $e t a l^{19}$ and was expressed as counts per minute $(\mathrm{cpm})$ per $\mu \mathrm{g}$ DNA.

\section{Expression of PDGF-R $\beta$}

Cells cultured on Nunc chamber slides (four separate cell preparations) were incubated in duplicate with or without $1 \mathrm{ng} / \mathrm{ml}$ TGF- $\beta 1$ for 48 hours. The cells were then immunostained. for PDGF-R $\beta$ according to the protocol described earlier. The primary antibody used was polyclonal rabbit anti-PDGF-R $\beta$ diluted 1 in 25. Horseradish peroxidase conjugated goat antirabbit IgG (diluted 1 in 100) was used as the secondary antibody and colour was developed using the Sigma liquid DAB substratechromogen system. Cells incubated with nonimmune rabbit serum served as negative controls.

\section{PROTEIN AND DNA DETERMINATIONS}

Protein content of cell lysates was measured by the method of Lowry et $a l^{17}$ using BSA as the standard. Pancreatic DNA was assayed by a modified fluorimetric microassay as described by Kapuscinski and Skoczylas ${ }^{20}$ using calf thymus DNA as the standard. 
A

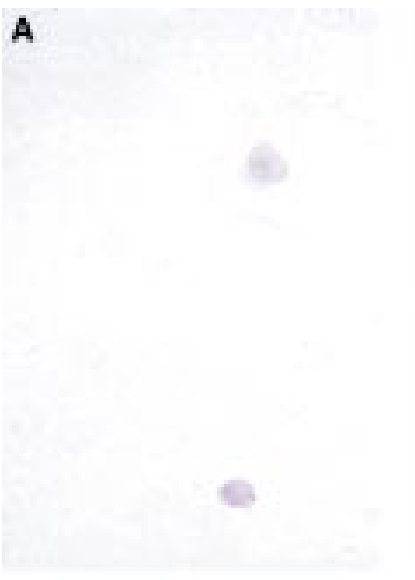

E

Figure 1 Pancreatic stellate cells in culture stained strongly positive for procollagen III, collagen I, laminin, and fibronectin (panels $B, D, F$, and $H$
respectively) compared with control cells incubated with the appropriate non-immune sera (panels A, C, E, and G respectively). Staining for the collagens and for laminin was perinuclear in distribution; that for fibronectin was diffuse.

STATISTICAL ANALYSIS

Results are expressed as mean (SEM) for five separate cell preparations per experimental protocol. Data were analysed using repeated measures analysis of variance (ANOVA). ${ }^{21}$ Fisher's protected least significant difference (PLSD) was used for comparison of individual groups provided that the $\mathrm{F}$ test was significant. $^{21}{ }^{22}$ The analyses were run on a Macintosh LC 630 personal computer using the Statview II statistical program.

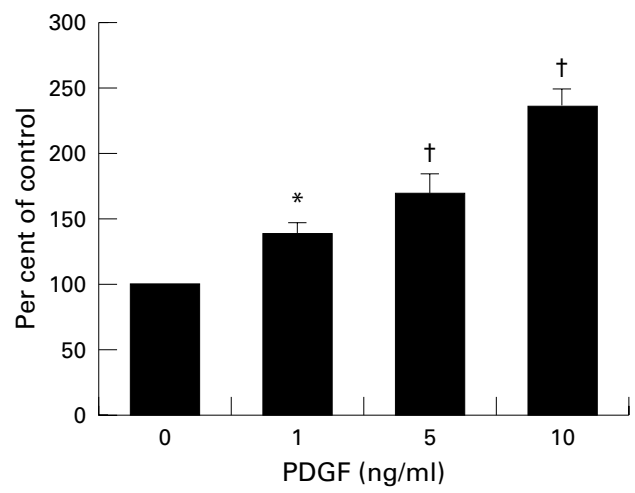

Figure 2 Effect of PDGF on cell counts (five separate cell preparations). Results are expressed as a percentage of control values (cells not incubated with PDGF). Increasing concentrations of PDGF resulted in a dose related increase in cell numbers $\left({ }^{\star} p<0.025, t p<0.001\right)$.
MATERIALS

All general chemicals were of analytical reagent grade and were purchased from Sigma Chemical Company (St Louis, Missouri, USA). Collagenase $\mathrm{P}$ was purchased from Boehringer Mannheim (Mannheim, Germany), collagenase type III (from Clostridium histolyticum) and protease type XIV (from Streptomyces griseus) were obtained from Sigma Chemical Company, and DNAse was purchased from Pharmacia Biotech (Uppsala, Sweden). Cell culture reagents were purchased from Sigma Chemical Company. Nycodenz was obtained from Nycomed Pharma AS (Oslo, Norway). Iscove's modified Dulbecco's medium was purchased from Gibco BRL. Antibodies were obtained from the following sources: polyclonal rabbit antihuman type III procollagen (Chemicon International, Temecula, California, USA), polyclonal rabbit antirat collagen type I (Amrad Pharmacia Biotech, Victoria, Australia), polyclonal rabbit antimouse laminin (Sigma Chemical Company), polyclonal rabbit antirat fibronectin (Calbiochem-Novabiochem Corp., San Diego, California, USA), and monoclonal antibody to $\alpha$ SMA (Sigma Chemical Company). ${ }^{3} \mathrm{H}$-thymidine (specific activity 6.7 $\mathrm{Ci} / \mathrm{mmol}$ ) was purchased from ICN Pharmaceuticals (Costa Mesa, California, USA), and ${ }^{14} \mathrm{C}$-proline (specific activity 250 $\mathrm{mCi} / \mathrm{mmol}$ ) was obtained from NEN (Boston, 


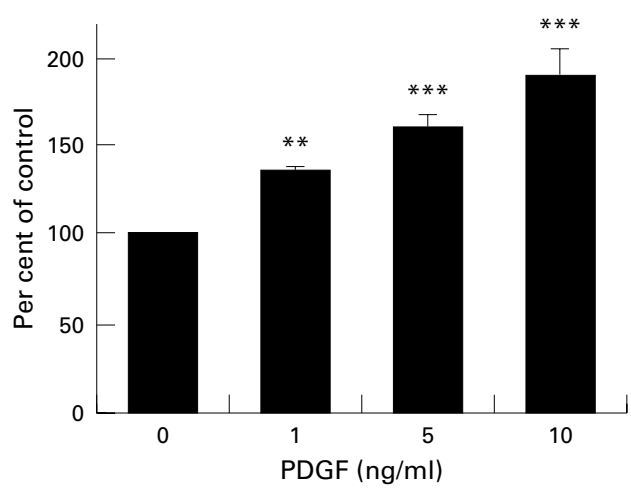

Figure 3 Effect of PDGF on DNA synthesis (five separate cell preparations). DNA synthesis was estimated by measuring the incorporation of ${ }^{3} \mathrm{H}$-thymidine into TCA precipitable material. Results are expressed as a percentage of control values observed in cells not incubated with PDGF ${ }^{\star *} p<0.01,{ }^{\star \star *} p<0.001$.

Massachusetts, USA). Human recombinant PDGF-BB and TGF- $\beta 1$ were purchased from Sigma Chemical Company.

ETHICS APPROVAL

This study was approved by the Animal Care and Ethics Committee of the University of New South Wales, Australia.

\section{Results}

IMMUNOSTAINING FOR ECM PROTEINS

Pancreatic stellate cells in late primary culture and early passage exhibited strong positive staining for all ECM proteins testedprocollagen III, collagen I, fibronectin, and laminin (fig 1). Staining for procollagen III and collagen I and laminin was predominantly perinuclear, whereas that for fibronectin was spread more diffusely in the cytoplasm.

EFFECT OF PDGF-BB ON CELL PROLIFERATION Cell counts

Increasing concentrations of PDGF-BB resulted in a dose dependent, statistically significant increase in cell numbers compared with control cells not incubated with PDGF. As

$\operatorname{MW}\left(\times 10^{3}\right)$

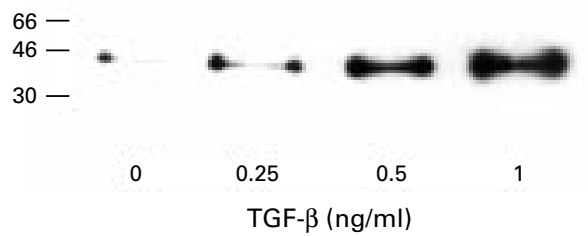

Figure 4 Western blot analysis of cell lysates for aSMA expression. The figure shows a representative immunoblot for expression in cells incubated with and without TGF- $\beta 1$. $A$ single band was detected in each lane corresponding to the known molecular weight (42 kDa) of aSMA.

Table 1 Effect of TGF- $\beta 1$ on a SMA concentrations in pancreatic stellate cells

\begin{tabular}{|c|c|}
\hline$T G F-\beta 1(n g / m l)$ & 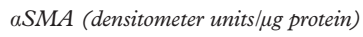 \\
\hline 0 & $0.04(0.006)$ \\
\hline $0.25^{\star}$ & $0.16(0.07)$ \\
\hline $0.5 \dagger$ & $0.23(0.07)$ \\
\hline $1 \dagger$ & $0.30(0.08)$ \\
\hline
\end{tabular}

Fisher's PLSD test: ${ }^{\star} \mathrm{p}<0.05 ; \mathrm{tp}<0.025$. depicted in fig 2, at a PDGF concentration of $10 \mathrm{ng} / \mathrm{ml}$, cell numbers were increased to 237 (13.1)\% of control values.

\section{${ }^{3} \mathrm{H}$-thymidine incorporation}

Similarly to the results obtained with cell counts, incorporation of radiolabelled thymidine was significantly increased in a dose related manner in cells exposed to increasing concentrations of PDGF-BB (fig 3), indicating an increased rate of DNA synthesis in response to PDGF.

EFFECT OF TGF- $\beta 1$ ON CELL ACTIVATION

aSMA expression

Immunoblotting for $\alpha S M A$ revealed a single band in each lane corresponding to the known molecular weight of $\alpha$ SMA (42 kilodaltons). A representative immunoblot in fig 4 shows the notable, dose dependent increase in aSMA protein expression observed with increasing concentrations of TGF- $\beta 1$. Densitometry of autoradiographs of immunoblots revealed a statistically significant increase in $\alpha$ SMA concentrations in cells incubated with TGF- $\beta 1$ compared with control cells (table 1).

\section{Collagen synthesis}

Collagen synthesis was expressed as cpm (counts per minute) in collagen per $\mu$ g DNA (fig 5). Stellate cells incubated with TGF- $\beta 1$ showed increased rates of collagen production compared with controls. Although the increases in collagen synthesis with the lower concentrations of TGF- $\beta 1 \quad(0.25$ and 0.5 $\mathrm{ng} / \mathrm{ml}$ ) were modest, a significant increase in collagen synthesis was observed in cells incubated with $1 \mathrm{ng} / \mathrm{ml}$ TGF- $\beta 1$.

\section{Expression of PDGF-R $\beta$}

Stellate cells stained positively for PDGF-R $\beta$ regardless of whether or not they were exposed to TGF- $\beta 1$. However the intensity of staining was notably greater in cells incubated with 1 $\mathrm{ng} / \mathrm{ml}$ TGF- $\beta 1$ (fig 6).

\section{Discussion}

This study showed that cultured rat pancreatic stellate cells have the capacity to produce collagen and other ECM proteins and are activated (exhibit increased proliferation, aSMA expression, and collagen synthesis) when exposed to the cytokines PDGF and TGF- $\beta$. In these respects, pancreatic stellate cells are similar to liver stellate cells (which are known to be central to hepatic fibrogenesis). This supports the notion that pancreatic stellate cells may play a role in the development of fibrosis in the pancreas.

Pancreatic fibrosis is a common response to chronic pancreatic injury from various causes including recurrent and/or persistent inflammation, alcohol abuse, malnutrition, and trauma. ${ }^{1}$ However, the pathogenesis of this constant feature of chronic pancreatitis has not yet been elucidated. In general, fibrosis represents a pathological change in the composition and amount of ECM in tissues. ${ }^{24}$ Fibrous/scar tissue consists of fibril forming collagens (types I and III) and other glycosylated proteins such 


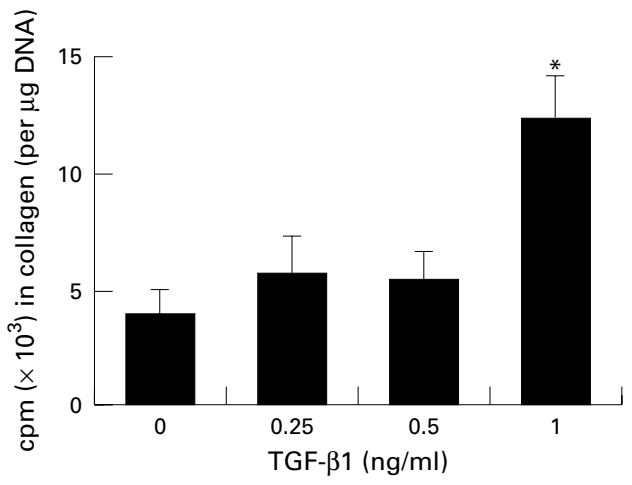

Figure 5 Effect of TGF- $\beta 1$ on collagen synthesis (five separate cell preparations). ${ }^{\star} p<0.005$.

as proteoglycans, fibronectin, and laminin. The present study has shown that pancreatic stellate cells in late primary culture and early passage stain strongly positive for collagen types I and III, fibronectin, and laminin - that is, they have the capacity to produce the proteins that constitute fibrous tissue. Procollagen III staining was also observed in early primary culture, at a time when collagen I staining was absent (data not shown). This observation is similar to that reported in cultured hepatic stellate cells where quiescent cells (in early culture) were found to produce predominantly collagen III whereas collagen I production was only observed in activated cells in late culture. ${ }^{23}$ Positive staining for laminin in pancreatic stellate cells also indicates transformation of these cells to a myofibroblast-like phenotype in culture, as distinct from fibroblasts which do not synthesise laminin. ${ }^{24}$

To support the hypothesis that pancreatic stellate cells play an active role in pancreatic fibrogenesis, it is essential to establish not only the capacity of these cells to produce ECM
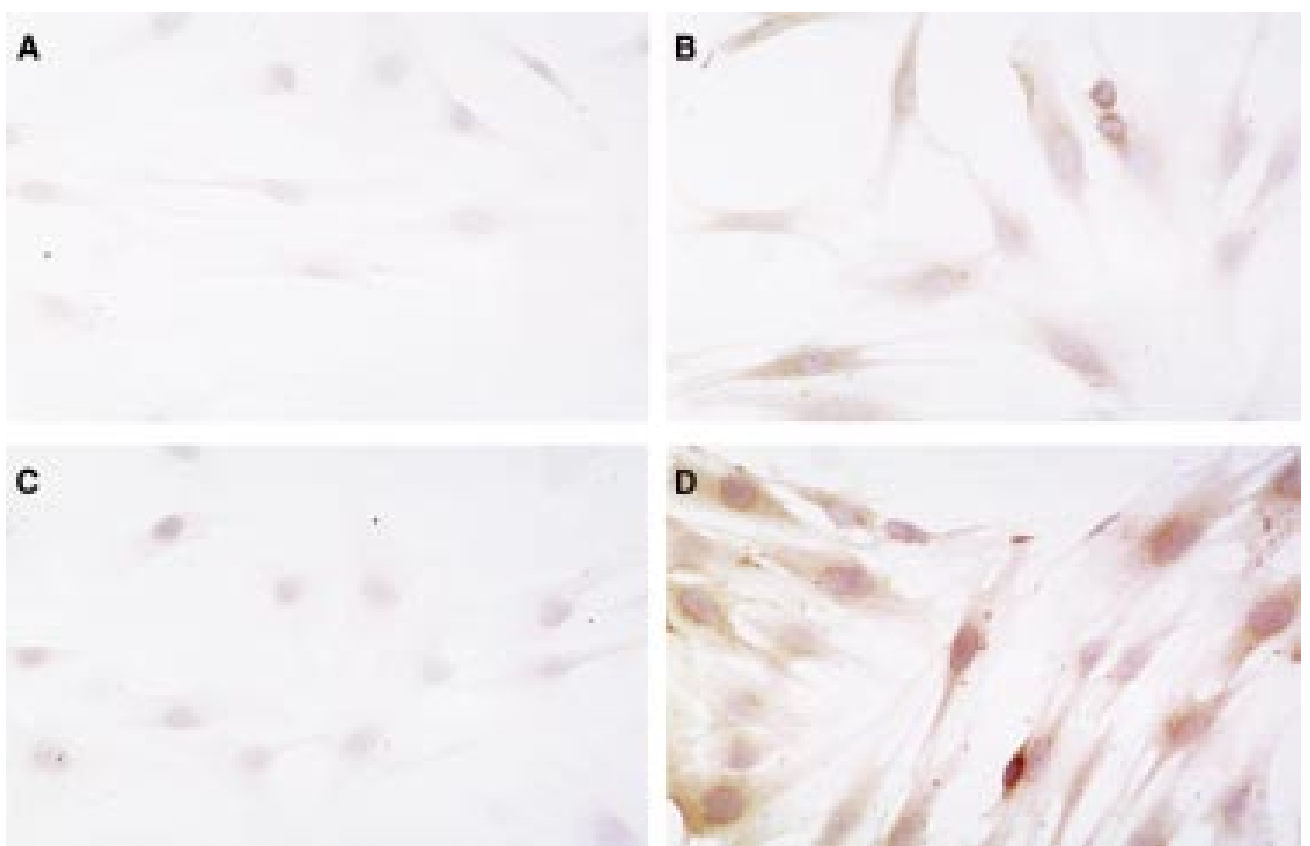

Figure 6 Effect of TGF- $\beta 1$ on expression of the $\beta$ subunit of the PDGF receptor (PDGF-R $\beta$ ). Panels $A$ and $B$ show stellate cells (not exposed to TGF- $\beta 1$ ) incubated with non-immune serum (negative control) and an antibody to $P D G F-R \beta$ respectively. Panels $C$ and $D$ show TGF- $\beta 1$ treated stellate cells incubated with non-immune serum (negative control) and an antibody to PDGF-R $\beta$ respectively. 
upregulation of PDGF receptors on the surface of stellate cells. In this regard, it is of interest to note that in a rat model of pancreatic fibrosis, immunostaining for PDGF receptor (known to bind the isoform PDGF-BB) was found to be notably increased in association with areas of fibrosis. ${ }^{10}$ This observation is in accord with the reports of increased PDGF receptor mRNA levels in cirrhotic human livers ${ }^{31}$ and in rat liver following acute $\mathrm{CCl}_{4}$ induced injury. ${ }^{32}$

The second cytokine examined in the present study was TGF- $\beta$, which is a homodimer composed of two identical subunits linked via disulphide bonds. ${ }^{33}$ Five homologous isoforms of this protein have been described; the most abundant isoform in the liver is TGF- $\beta 1 .^{34}$ This isoform of TGF- $\beta$ plays a regulatory role in the biosynthesis and turnover of the ECM and is the most potent fibrogenic mediator described for hepatic stellate cells. ${ }^{35}$ Transformation to a myofibroblast-like phenotype and stimulation of collagen synthesis have been shown in cultured hepatic stellate cells exposed to TGF- $\beta 1 .{ }^{36}$ The role of TGF- $\beta 1$ in pancreatic disease has been studied in experimental models of acute pancreatitis as well as in human chronic pancreatitis. Repeated injections of TGF- $\beta 1$ after recurrent episodes of acute pancreatitis in mice have been reported to promote the development of pancreatic fibrosis. ${ }^{37}$ In a rat model of caerulein induced pancreatitis, increased protein and $\mathrm{mRNA}$ levels of TGF- $\beta 1$ were observed (during the regeneration phase) associated with collagen deposition and increased mRNA levels for collagen types I and III. ${ }^{38}$ Furthermore, inhibition of TGF- $\beta 1$ by administration of a neutralising antibody in the above rat model was found to reduce collagen synthesis and ECM deposition. ${ }^{39}$ In human chronic pancreatitis, TGF- $\beta 1$ expression has been shown to be increased in association with areas of fibrosis. ${ }^{40}$

In the present study, we have shown that TGF- $\beta 1$ induces the transformation of pancreatic stellate cells to myofibroblasts (as evidenced by increased aSMA expression) and also stimulates collagen synthesis in these cells. These results suggest that the observed effect of TGF- $\beta$ on pancreatic collagen synthesis during pancreatic injury in vivo may be mediated via activation of stellate cells in the gland. An additional observation made in this study was the induction of PDGF receptor expression in cells exposed to TGF- $\beta 1$. This observation is similar to that described in stellate cells cultured from human liver where expression of PDGF-R $\beta$ was increased at both the mRNA and protein level in cells exposed to $1 \mathrm{ng} / \mathrm{ml} \mathrm{TGF}-\beta 1 .{ }^{16}$ TGF- $\beta 1$ induced upregulation of PDGF receptors could have implications for the perpetuation of fibrogenesis in vivo. Increased expression of cell surface receptors would result in increased responsiveness of stellate cells to PDGF and a consequent perpetuation of the activated state of these cells.

In conclusion, the results of this study provide information regarding potential mechanisms leading to the development of pancreatic fibrosis. We have shown that the pancreas contains cells that are similar, not only morphologically but also functionally, to the cells known to be primarily responsible for fibrogenesis in the liver. Thus the findings of this study provide support for the concept that pancreatic stellate cells, when activated by profibrogenic mediators, have the potential to play an important role in pancreatic fibrogenesis.

1 DiMagno EP, Layer P, Clain JE. Chronic pancreatitis. In: Go VLW, DiMagno EP, Gardner JD, et al, eds. The pancreas: VLW, DiMagno EP, Gardner JD, et al, eds. The pancreas:
biology, pathobiology and disease. New York: Raven Press, biology, pathobiolog

2 Friedman SD. The cellular basis of hepatic fibrosis. N Engl F Med 1993;328:1828-35.

3 Gressner AM, Bachem MG. Molecular mechanisms of liver fibrogenesis - a homage to the role of activated fat-storing cells. Digestion 1995;56:335-46.

4 Day CP. Is necroinflammation a prerequisite for fibrogenesis? Hepatogastroenterology 1996;43:104-20

5 Gressner AM. Cytokines and cellular crosstalk involved in the activation of fat-storing cells. F Hepatol 1995;22:28-36.

6 Parola M, Pinzani M, Casini A, et al. Stimulation of lipid peroxidation or 4-hydroxynonenal treatment increases procollagen alpha 1 (I) gene expression in human liver fat-storing cells. Biochem Biophys Res Commun 1993;194: fat-storing

7 Beno DWA, Retsky JE, Davis BH. Lipid peroxidationBeno DWA, Retsky JE, Davis BH. Lipid peroxidation-
induced isoprostane independently activates Ito cell MAP induced isoprostane independently activates Ito cell MAP [abstract]. Hepatology 1994;20:291A.

8 Gressner AM, Schafer S. Comparison of sulphated glycosaminoglycan and hyaluronate synthesis and secretion in cultured hepatocytes, fat storing cells, and Kupffer cells. f Clin Chem Clin Biochem 1989;27:141-9.

9 Apte MV, Haber PS, Applegate TL, et al. Periacinar stellateshaped cells in rat pancreas: identification, isolation and culture. Gut 1998;43:128-33.

10 Haber PS, Keogh GW, Apte MV, et al. Pancreatic stellate cells are activated in human and experimental pancreatitis [abstract]. Gastroenterology 1998;114:A466.

11 Farkas G. Inflammatory mediators in acute pancreatitis (theoretical considerations). Orvosi Hetilap 1995;136: 1819-22.

12 Kusske AM, Rongione AJ, Reber HA. Cytokines and acute pancreatitis. Gastroenterology 1996;110:639-42.

13 Braganza JM, Scott P, Bilton D, et al. Evidence for early oxidative stress in acute pancreatitis. Clues for correction. Int 7 Pancreatol 1995;17:69-81.

14 Norton ID, Apte MV, Lux O, et al. Chronic ethanol administration causes oxidative stress in the rat pancreas. $f \mathrm{Lab}$ Clin Med 1998;131:442-6.

15 Schafer S, Zerbe O, Gressner AM. The synthesis of proteoglycans in fat-storing cells of rat liver. Hepatology 1987;7:680-7.

16 Pinzani M, Gentilini A, Caligiuri A, et al. Transforming growth factor-beta 1 regulates platelet-derived growth factor receptor beta subunit in human liver fat-storing cells. Hepatology 1995;21:232-9.

17 Lowry OH, Rosebrough NJ, Farr AL, et al. Protein measurement with the folin phenol reagent. $\mathcal{F}$ Biol Chem 1951;193:265-75.

18 Agelli M, Wahl SM. Collagen production by fibroblasts. Methods Enzymol 1988;163:643-56.

19 Peterkofsky B, Chojkier M, Bateman J. Determination of collagen synthesis in tissue and cell culture systems. In: Furthmayer $\mathrm{H}$, ed. Immunochemistry of the extracellular matrix. Vol II. Boca Raton, Florida: CRC Press, 1981: $19-47$

20 Kapuscinski J, Skoczylas B. Simple and rapid fluorimetric method for DNA microassay. Anal Biochem 1977;83:2527.

21 Snedecor GW, Cochran WG. Statistical methods. 8th edn. Ames, Iowa: Iowa State University Press, 1989.

22 Feldman DS Jr, Hofmann R, Gagnon J, et al. Statview II. Berkeley, California: Abacus Concepts Inc, 1987.

23 Burt AD. Cellular and molecular aspects of hepatic fibrosis. 7 Pathol 1993;170:105-14.

24 Foidart JM, Bere EWJ, Yaar M, et al. Distribution and immunoelectron microscopic localization of laminin, a immunoelectron microscopic localization of laminin, a Invest 1980;42:336-42.

25 Friedman SL, Arthur MJP. Activation of cultured rat hepatic lipocytes by Kupffer cell conditioned medium: direct enhancement of matrix synthesis and stimulation of cell proliferation via induction of platelet-derived growth factors. F Clin Invest 1989;84:1780-5.

26 Pinzani M, Gesualdo L, Sabbah GM, et al. Effects of platelet-derived growth factor and other polypeptide mitogens on DNA synthesis and growth of cultured rat liver fat-storing cells. $\mathcal{F}$ Clin Invest 1989;84:1786-93.

27 Ross R. Platelet-derived growth factor. Lancet 1989;i:117982.

28 Pinzani M, Knauss TC, Pierce GF, et al. Mitogenic signals for platelet-derived growth factor isoforms in liver fatstoring cells. Am f Physiol 1991;260:C485-91.

29 Mene P, Abboud HE, Dubyak GR, et al. Effect of PDGF on inositol phosphates, $\mathrm{Ca}^{2+}$ and contraction of mesangial cells. Am f Physiol 1987;253:F458-63. 
30 Wahl MI, Olashaw NE, Nishibe S, et al. Platelet-derived growth factor induces rapid and sustained tyrosine BALB/c 3T3 cells. Mol Cell Biol 1989;9:2934-43.

31 Pinzani M, Milani S, Herbst H, et al. Expression of plateletderived growth factor and its receptors in normal human liver and during active hepatic fibrogenesis. Am $\mathcal{F}$ Pathol 1996;148:785-800.

32 Pinzani M, Milani S, Grappone C, et al. Expression of platelet-derived growth factor in a model of acute liver injury. Hepatology 1994;19:701-7.

33 Bedossa P, Paradis V. Transforming growth factor- $\beta$ (TGF$\beta)$ : a key role in hepatic fibrogenesis. F Hepatol 1995;22:3742 .

34 Jakowlew SB, Mead JE, Danielpour D, et al. Transforming growth factor isoforms in rat liver regeneration: messenger RNA expression and activation of latent TGF-beta. Cell Regul 1991;2:535-48.

35 Bachem MG, Meyer D, Melchior R, et al. Activation of rat liver perisinusoidal lipocytes by transforming growth liver perisinusoidal lipocytes by transforming growth self-perpetuation in liver fibrogenesis. $\mathcal{f}$ Clin Invest
1992;89:19-27.

36 Matsuoka M, Pham NT, Tsukamoto H. Differential effects of interleukin-1 alpha, tumor necrosis factor alpha, and transforming growth factor beta 1 on cell proliferation and collagen formation by cultured fat-storing cells. Liver 1989;9:71-8.

37 Van Laethem J-L, Robberecht P, Resibois A, et al. Transforming growth factor promotes development of fibrosis after repeated courses of acute pancreatitis. Gastroenterology 1996;110:576-82.

38 Gress T, Muller-Pillasch F, Elsasser HP, et al. Enhancement of transforming growth factor $\beta 1$ expression in the rat pancreas during regeneration from cerulein-induced pancreatitis. Eur 7 Clin Invest 1994;24:679-85.

39 Menke A, Yamaguchi H, Gress TM, et al. Extracellular matrix is reduced by inhibition of transforming growth factor $\beta 1$ in pancreatitis in the rat Gastroenterology 1997;113: $295-303$.

40 Van Laethem J-L, Deviere J, Resibois A, et al. Localisation of transforming growth factor $\beta 1$ and its latent binding protein in human chronic pancreatitis. Gastroenterology protein in human 